\title{
Familial spastic paraplegia with Kallmann's syndrome
}

\author{
RR TUCK, * BP O’NEILL, ${ }^{*}$ H GHARIB, $\dagger$ DW MULDER* \\ From the Departments of Neurology* and Endocrinology, $\uparrow$ Mayo Clinic, Rochester, Minnesota, USA
}

SUMMARY A sibship is reported in which two males have spastic paraparesis and Kallmann's syndrome (hypogonadotrophic hypogonadism and anosmia). One of the brothers also is colourblind. The association of familial spastic paraplegia and Kallmann's syndrome has not been described previously.

Hypogonadism which is secondary to inadequate gonadotrophin release by the anterior pituitary in the presence of otherwise normal hypophysealhypothalamic function has been reported in patients with a variety of neurological disorders, some of which may be familial. These include cerebellar ataxia, ${ }^{1-7}$ the syndrome of "ophthalmoplegia plus," Moebius' syndrome with peripheral neuropathy, ${ }^{9-11}$ dystrophia myotonica, ${ }^{12}$ hereditary bimanual synkinesis, ${ }^{13}{ }^{14}$ Rud's syndrome, ${ }^{15}$ Laurence-Moon-Biedl syndrome, ${ }^{16}$ colour-blindness, ${ }^{13}$ nerve deafness ${ }^{18}$ and anosmia..$^{1317} 18$ The combination of hypogonadotrophic hypogonadism and anosmia is known as Kallmann's syndrome. ${ }^{13}$ Here we describe a family in which two sons are affected with both spastic paraparesis and Kallmann's syndrome.

\section{Cases reports}

A pedigree chart of the family is shown in the figure. III-4: $M r E K, 26 \mathrm{yr}$, was noted to be hypogonadal at age 14 yr. After excision of the left undescended testis and biopsy of the right, he received injections of human chorionic gonadotrophin (HCG) and then testosterone. In 1975 he had high plantar arches, mild distal arm and leg weakness and normal reflexes. His plasma testosterone was $0.45 \mathrm{nmol} / 1$ (normal range 10-42), follicle stimulating hormone (FSH) 0.42 IU/1 (normal range 0.33-5.0) and luteinizing hormone (LH) $2 \cdot 5 \mathrm{IU} / 1$ (normal range 3.2-23). No Barr bodies were seen in a buccal smear. Radiographs of the pituitary fossa were normal. He received methyl testosterone, $25 \mathrm{mg} /$ day. By October of 1979 he was unable to walk. Three myelograms were performed over the following two years and were normal. In February 1982, he complained of increasing upper limb weakness and urgency of both micturition and defaecation. On examination, he was tall $(190 \mathrm{~cm})$ and obese and had rela-

Address for reprint requests: Dr RR Tuck, Department of Neurology, Mayo Clinic, Rochester, Minnesota 55905, USA.

Received 21 October 1982 and in revised form 22 January 1983. Accepted 4 March 1983 tively sparse facial, axillary and pubic hair. There was no gynecomastia; the penis was normal, the left testis absent and the right small and soft. Neurological examination revealed anosmia, red-green colour-blindness, and inability to elevate the left eye. The cranial nerves were otherwise normal. There was mild weakness of the shoulder girdle muscles and biceps brachii on the right and of the forearm and intrinsic hand muscles bilaterally. There was severe weakness of the abdominal muscles and all muscle groups in the lower limbs. Reflexes were normal in the arms but symmetrically increased in the legs. Babinski signs were present bilaterally and there was moderate spasticity at the knees. Coordination was normal. Appreciation of light touch and pinprick, and two point discrimination were impaired distally in the arms. All modalities of sensation were impaired in the distal legs. Bilateral pes cavus was present.

\section{Investigations}

The following investigations were normal: complete blood count, red cell morphology, sedimentation rate, plasma glucose, very long chain fatty acids, (by courtesy of Dr Hugo W Moser, Baltimore) serum electrolytes, creatinine, cholesterol, protein electrophoresis, antinuclear antibody, total and free thyroxine, adrenocorticotrophic hormone (ACTH), cortisol, prolactin, bilirubin, alkaline

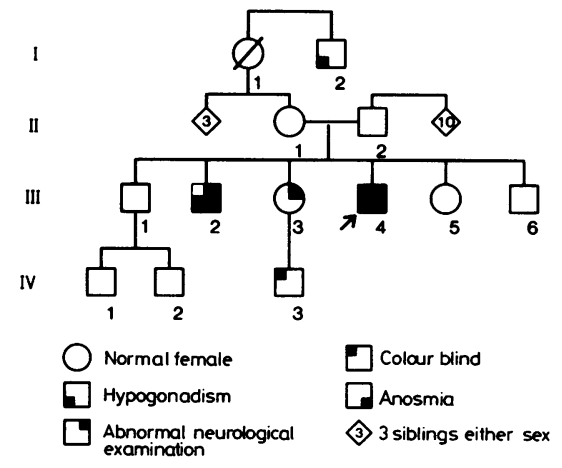

Fig Pedigree chart of $K$ family. The index case is indicated with an arrow. 
Table Results of nerve conduction studies on index case, his two sisters and his mother ( $L=$ latency; $V=$ velocity; $A=$ amplitude; $N R=$ no action potential recordable). Control values indicate normal values for our EMG laboratory.

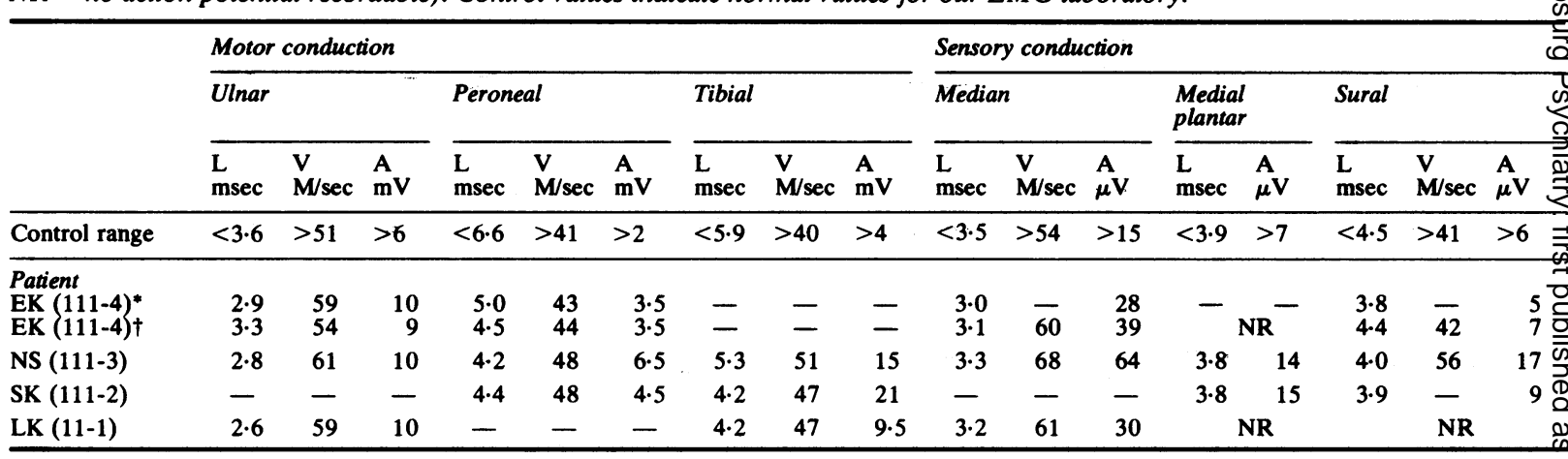

* = studies performed in $1977 ; \dagger=$ studies performed in 1982.

phosphatase, alanine aminotransferase, vitamin B12, phytanic acid, tests for syphilis, chest radiograph, urinalysis, urine arylsulfatase $\mathbf{A}$, arsenic and lead, and visual and brainstem evoked potentials. Serum folate was low $(1.4 \mu \mathrm{g} / \mathrm{l}$; normal range $2-20)$ and triglycerides were elevated (3.03 mmol// upper limit of normal 1.77). A head CT scan revealed mild enlargement of the lateral ventricles. An EMG demonstrated failure to activate motor unit potentials suggesting an upper motor neuron lesion. Nerve conduction studies are summarised in the table. He was given folate supplements and physical therapy, and testosterone was continued.

III-2: $M r S K$, aged $30 \mathrm{yr}$, had a mild spastic paraparesis at age 11 yr when an EEG, cerebrospinal fluid (CSF)-examination, myelogram, and psychometric tests were normal. At age 17, he was found to be anosmic and to have low serum testosterone and gonadotrophins. A diagnosis of Kallmann's syndrome was made and he was treated with intramuscular testosterone. He has had no neurological complaints. On examination in February 1982, he was tall $(198 \mathrm{~cm})$ and obese with thoracic scoliosis and bilateral pes cavus. He had a spastic gait and could not walk on his heels or toes. He was anosmic and unable to elevate the right eye; cranial nerves were otherwise normal. In the arms there was slight symmetrical weakness of the forearm and intrinsic hand muscles and in the legs there was moderate weakness of the ankle dorsiflexors, evertors and plantar flexors and of the toe extensors and flexors. All deep. tendon reflexes were brisk and Babinski signs were present bilaterally. There was poorly sustained ankle clonus and marked spasticity at the knees. Coordination was normal. Appreciation of touch, temperature and joint position was normal, but appreciation of pinprick was diminished in the toes. Nerve conduction studies were normal (table).

III-3: NS, age $28 \mathrm{yr}$, has high plantar arches, tight Achillles tendons and slight weakness of foot and ankle muscles. The knee and ankle jerks are brisk but the plantar responses flexor. Muscle tone and coordination are normal. Appreciation of pinprick is diminished in the feet and toes but other modalities are normal. An EMG and nerve conduction studies are normal (table).

$I V-3: A S$, aged $3 \mathrm{yr}$, is colour-blind, has an intact sense of smell and a normal neurological examination.
I-2: $O L$, was not available for examination but he was investigated at another institution for hypogonadism. The status of his olfaction and colour vision is not known. His family reports that he walks normally.

No abnormalities were found in the clinical examination of II-1, II-2, III-5, or III-6; III-1 was not examined but he and his two sons are apparently healthy.

\section{Discussion}

The neurological findings in the two affected males in this family closely resemble those of familial spastic paraplegia ${ }^{19}$ although sensory loss in the extremities is not typical of the pure form. ${ }^{20}$ Another atypical feature is the presence of partial monocular external ophthalmoplegia. Extra-ocular movements are usually normal in familial spastic paraplegia although Alajouanine and Nick $^{21}$ described two brothers who had spastic paraparesis, a supranuclear paralysis of upward gaze, weakness of facial and bulbar muscles and cerebellar signs.

The medial plantar nerve sensory action potential was absent in the index case. McLeod et al,,$^{22}$ and Harding ${ }^{20}$ reported that nerve conduction studies were normal in pure familial spastic paraplegia although Dyck ${ }^{23}$ states that abnormalities of sensory conduction and quantitative histological abnormalities are present in the sural nerves of patients with familial spastic paraplegia.

Most families with familial spastic paraplegia demonstrate autosomal dominant inheritance although an autosomal recessive form exists. ${ }^{19} 20 \mathrm{~A}$ number of kindreds with apparent X-linked inheritance have also been reported..$^{24-29}$ In the present family, the mode of inheritance of familial spastic paraplegia is uncertain. The mild neurological abnormalities in III-3 and absent medial plantar and sural nerve action potentials in II-1 are possibly of no significance but would be consistent with both 
$\mathrm{X}$-linked recessive inheritance with partial expression in hemizygotes ${ }^{30}{ }^{31}$ and male-limited autosomal dominant inheritance. Harding ${ }^{20}$ demonstrated that expression of dominantly inherited familial spastic paraplegia may be very mild in some females so the possibility of dominant inheritance cannot be excluded. Autosomal recessive familial spastic paraplegia is also possible in this family.

It is now known that hypogonadism in Kallmann's syndrome is secondary to failure of the anterior pituitary to release adequate quantities of gonadotrophins $^{17}$ while the release of other trophic hormones is normal. ${ }^{16}$ Males and co-workers ${ }^{32}$ have suggested that the disorder is due to abnormal hypothalamic regulation of releasing factors although the mechanism is unknown. Unfortunately, very little information is available concerning the neuropathology of Kallmann's syndrome. DeMorsier and Gauthier ${ }^{33}$ reported absence of the olfactory bulbs and hypoplasia of the hypothalamus in three patients. Absence of the olfactory bulbs has also been observed at craniotomy in one patient. ${ }^{32}$

The pattern of inheritance of Kallmann's syndrome is uncertain. $\mathrm{X}$-linked recessive, $\mathrm{X}$-linked dominant, and autosomal dominant modes have all been suggested. ${ }^{174}{ }^{35}$ Father to son transmission has been documented in one family ${ }^{36}$ in which the father was treated with gonadotrophins which suggests autosomal dominant inheritance. The fact that females may be affected in some families ${ }^{32}{ }^{35}$ also favours autosomal rather than X-linked inheritance although certain $X$-linked disorders may be manifest in the hemizygous female. ${ }^{3031}$ Some relatives of patients with Kallmann's syndrome may have either anosmia or hypogonadism, but not both traits, ${ }^{34}{ }^{35}$ suggesting that two linked genes may be responsible for Kallmann's syndrome. In the present family the mode of inheritance of Kallmann's syndrome cannot be stated with certainty. That the mother's maternal uncle is hypogonadal suggests that the mother is a carrier but whether the gene is X-linked or malelimited autosomal dominant cannot be determined.

The presence of both familial spastic paraplegia and Kallmann's syndrome in these two brothers might be due to inheritance of two abnormal genes. This could be a result of either chance concurrence or genetic linkage. It is unlikely that both familial spastic paraplegia and Kallmann's syndrome are due to a single abnormal gene because the mother's maternal uncle, who is known to be hypogonadal, is believed to have no neurological abnormality.

Dr RR Tuck was in receipt of a Thomas and Ethel Mary Ewing Scholarship in Medicine (University of Sydney, Australia) and a Fulbright Postgraduate Student Grant.

\section{References}

' Vignalou J, Berthaux P, Gouygou Q, Colas Belcour JF, Lemarchal A, Hammel A. Hypogonadisme hypogonadotrophique associé à une maladie de Friedereich. Ann Endocrinol (Paris) 1959;20:172-7.

${ }^{2}$ Bernard-Weil E, Endtz L-J. Sur un cas familial de dégénération spinocerebelleuse avec eunuchoidisme hypogonadotrophique. Présse Medicale 1962;70:524-6.

${ }^{3}$ Volpe R, Metzler WS, Johnston MW. Familial hypogonadotrophic eunuchoidism with cerebellar ataxia. J Clin Endocrinol 1963;23:107-15.

4 Matthews WB, Rundle AT. Familial cerebellar ataxia and hypogonadism. Brain 1964;87:463-8.

5 Boucher BJ, Gibberd FB. Familial ataxia, hypogonadism and retinal degeneration. Acta Neurol Scand 1969;45:507-10.

- Neuhauser G, Opitz JM. Autosomal recessive syndrome of cerebellar ataxia and hypogonadotrophic hypogonadism. Clin Genet 1975;7:426-34.

' Lowenthal A, Bekaert J, Van Dessel F, Van Hanwert J. Familial cerebellar ataxia with hypogonadism. $J$ Neurol 1979;222:75-80.

${ }^{8}$ Carton H, Gybels J, Brucher JM. Ocular myopathy with perpubertal functional castration syndrome. Acta Neurol Belg 1969;69:265-71.

${ }^{9}$ Olson WH, Bardin CW, Walsh GO, Engel WK. Moebius' syndrome. Lower motor neuron involvement and hypogonadotrophic hypogonadism. Neurology (Minneap) 1970;20:1002-8.

${ }^{10}$ Rubinstein A, Lovelace RE, Behrens MM, Weisberg LA. Moebius' syndrome in association with peripheral neuropathy and Kallmann's syndrome. Arch Neurol 1975;32:480-2.

" Abid F, Hall R, Hudgson P, Weiser R. Moebius' syndrome, peripheral neuropathy and hypogonadotrophic hypogonadism. I. Neurol Sci 1978;35:309-15.

12 Ulloa-Aquirre A, Larrea F, Skurovich M. Hypothalamic hypogonadism in myotonic dystrophy. Obstet Gynecol 1981;57:675-95.

${ }^{13}$ Kallmann FJ, Schoenfeld WA, Barrera SE. The genetic aspects of primary eunuchoidism. Am.J Ment Defic 1944;48:203-36.

${ }^{14}$ Conrad B, Kriebel J, Hetzel WD. Hereditary bimanual synkinesis combined with hypogonadotrophic hypogonadism and anosmia in four brothers. $J$ Neurol 1978;218:263-74.

is Maldonado RR, Tamayo L, Carnevale A. Neuroichthyosis with hypogonadism (Rud's syndrome). Int $J$ Dermatol 1975;14:347-52.

${ }^{16}$ Bardin CW. Hypogonadotrophic hypogonadism in patients with multiple congenital defects. Birth Defects 1971;7:175-8.

${ }^{17}$ Sparkes RS, Simpson RW, Paulsen CA. Familial hypogonadotrophic hypogonadism with anosmia. Arch Int Med 1968;121:534-8.

${ }^{18}$ Bardin CW, Ross GT, Rifkind AB, Cargille CM, Lipsett MB. Studies of the pituitary-Leydig cell axis in young men with hypogonadotrophic hypogonadism and hyposmia: comparison with normal men, perpubertal boys, and hypopituitary patients. J Clin Invest 1969;48:2046-56. 
${ }^{19}$ Sutherland JM. Familial spastic paraplegia. In: Vinken PJ and Bruyn GW, eds. Handbook of Clinical Neurology, North Holland Publishing Company, Amsterdam 1975;22:421-31.

${ }^{20}$ Harding AE. Hereditary "pure" spastic paraplegia: a clinical and genetic study of 22 families. J Neurol, Neurosurg Psychiatry 1981;44:871-83.

${ }^{21}$ Alajouanine TH, Nick J. Paraplégie spasmodique familiale avec troubles cérébelleux et paralysie verticale du regard (presentation de deux frères). Rev Neurol (Paris) 1951;84:182-5.

${ }^{22}$ McLeod JG, Morgan JA, Reye C. Electrophysiological studies in familial spastic paraplegia. J Neurol, Neurosurg Psychiatry 1977;40:611-5.

${ }^{23}$ Dyck PJ. Inherited neuronal degeneration and atrophy affecting peripheral motor, sensory and autonomic neurons. In Dyck PJ, Lambert EH and Thomas PK, eds. Peripheral Neuropathy, Philadelphia WB Saunders \& Co 1975:825-67.

${ }^{24}$ Zatz M, Penha-Serrano C, Otto PA. X-linked recessive type of pure spastic paraplegia in a large pedigree: absence of detectable linkage with $\mathrm{Xg}$. J Med Genet 1976;13:217-22.

${ }^{25}$ Wolfast W. Eine Sippe mit recessiver geschletsgebundener spastischer Diplegie. Zeitschrift für Menschliche Verebungsund Konstitutionslehre 1943;27:189-98.

${ }^{26}$ Blumel J, Evans EB, Eggers GWN. Hereditary cerebral palsy. A preliminary report. J Pediatr 1957;50:454-8.

${ }^{27}$ Johnston AW, McKusick VA. A sex-linked recessive form of spastic paraplegia. American Journal of Human Genetics 1961;13:83-93.

${ }^{28}$ Baar HS, Gaarland AM. Sex-linked spastic paraplegia. Am J Ment Defic 1966;71:13-8.

${ }^{29}$ Thurmon TF, Walker BA, Scott CI, Abbott MH. Two kindreds with a sex-linked recessive form of spastic paraplegia. Birth Defects 1971;7:219-21.

${ }^{30}$ Lyon ME. Genetic factors on the X chromosome. Lancet 1961;2:434.

${ }^{31}$ O'Neill BP, Moser HW, Saxena KM, Marmion LC. Adrenoleukodystrophy (ALD): Neurologic disease in carriers and correlation with very long chain fatty acid (VLCFA) concentrations in plasma and cultured skin fibroblasts. Neurology (NY) 1982;32:A216-217.

${ }^{32}$ Males JL, Townsend JL, Schneider RA. Hypogonadotrophic hypogonadism with anosmia: Kallmann's syndrome. Arch Int Med 1973;131:501-7.

${ }^{33}$ De Morsier G, Gauthier G. La dysplasie olfactogénitale. Pathol Biol (Paris) 1963;11:1267-72.

${ }^{34}$ Nowakowski H, Lenz W. Genetic aspects in male hypogonadism. Recent Progress in Hormone Research 1961;17:53-89.

${ }^{35}$ Santen RJ, Paulsen CA. Hypogonadotrophic eunuchoidism I. Clinical study of the mode of inheritance.J Clin Endocrinol Metab 1973;36:47-54.

${ }^{36}$ Merriam GR, Beitins IZ, Bode HH. Father to son transmission of hypogonadism with anosmia: Kallmann's syndrome. Am J Dis Children 1977;131:1216-9. 